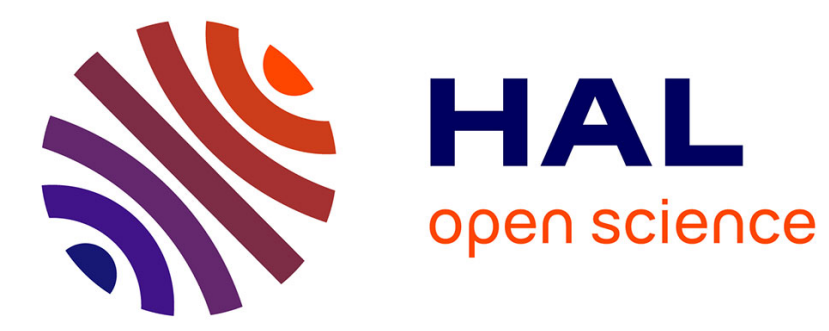

\title{
IEEE European Test Symposium (ETS)
}

\author{
S. Eggersglüss, S. Hamdioui, A. Jutman, M.K. Michael, J. Raik, M. Sonza \\ Reorda, Mehdi B. Tahoori, Elena Ioana Vatajelu
}

\section{To cite this version:}

S. Eggersglüss, S. Hamdioui, A. Jutman, M.K. Michael, J. Raik, et al.. IEEE European Test Symposium (ETS). IEEE International Test Conference (ITC'2019), Nov 2019, Washington DC, United States. pp.1-4, 10.1109/ITC44170.2019.9000148 . hal-02506911

\section{HAL Id: hal-02506911 \\ https://hal.science/hal-02506911}

Submitted on 12 Nov 2020

HAL is a multi-disciplinary open access archive for the deposit and dissemination of scientific research documents, whether they are published or not. The documents may come from teaching and research institutions in France or abroad, or from public or private research centers.
L'archive ouverte pluridisciplinaire HAL, est destinée au dépôt et à la diffusion de documents scientifiques de niveau recherche, publiés ou non, émanant des établissements d'enseignement et de recherche français ou étrangers, des laboratoires publics ou privés.

\section{다)(1) $(5$}

Distributed under a Creative Commons Attribution - NonCommerciall 4.0 International 


\section{IEEE European Test Symposium (ETS)}

\author{
Stephan Eggersglüß \\ Mentor, A Siemens Business \\ Hamburg, Germany
}

\author{
Jaan Raik \\ Tallin University of Technology \\ Tallin, Estonia
}

\author{
Said Hamdioui \\ Technical University of Delft \\ Dependable and Emerging \\ Computer Technologies \\ Delft, Netherlands
}

\author{
Matteo Sonza Reorda \\ Politecnico di Torino \\ Dipartimento di Automatica e \\ Informatica \\ Torino, Italy
}

\author{
Artur Jutman \\ Testonica Lab \\ Tallin University of Technology \\ Tallin, Estonia
}

\author{
Mehdi Tahoori \\ Karlsruhe Institute of Technology \\ Dependable Nano-Computing \\ Karlsruhe, Germany
}

\author{
Maria K. Michael \\ University of Cyprus \\ KIOS Research and Innovation \\ Center of Excellence \\ Nicosia, Cyprus \\ Elena-IoanaVatajelu \\ TIMA Laboratory \\ CNRS/UGA/INPG \\ Grenoble, France
}

\begin{abstract}
This paper is dedicated to the IEEE European Test Symposium (ETS). It offers an overview of all the European Test Workshop and Symposium events, from its first edition in 1996 to the next edition in 2020.
\end{abstract}

\section{INTRODUCTION}

The IEEE European Test Symposium (ETS) is Europe's premier forum dedicated to presenting and discussing scientific results, emerging ideas, applications, hot topics and new trends in the area of electronic-based circuits and system testing, reliability, security and validation. The areas of interest include (but are not limited to) the following topics: Analog, Mixedsignal and RF Test; ATE Hardware and Software; Automatic Test Generation; Board Test and Diagnosis; Boundary Scan Test; Built-In Self-Test (BIST); Current-Based Test; DefectBased Test; Delay and Performance Test; Dependability and Functional Safety; Design for Test (DFT); Design for Manufacturing (DFM); Design Verification and Validation; Diagnosis and Silicon Debug; Economics of Test; Failure Analysis; Fault Modeling and Simulation; Fault Tolerance; Hardware Trojans; Hardware Security; High-Speed I/0 Test; GPU Test; Low-Power IC Test; Memory Test and Repair; MEMS Test; Microprocessor Test; Multi-/Many-core Processor Test; Nanotechnology Test; On-line Test; Power Issues in Test; Design for Reliability; Reliability-Security Trade-offs; Security Issues in Test; Self-Repair; Signal Integrity Test; Stacked or 3D ICs Test; Standards in Test; System Test; SiP and SoC Test; Test Synthesis; Test, Reliability and Security of Emerging Technologies and Architectures; Test of Reconfigurable Systems; Test Quality; Thermal Issues in Test; Transient and Soft Errors; Variability Issues in Test; Yield Analysis and Enhancement.

This paper offers an overview of all the European Test Workshop and Symposium events, from the first edition in 1996 to the next edition in 2020. Its purpose is three-fold: (i) to take the reader through a journey of ETS past events, (ii) to acknowledge all those who, through their vision, hard work and dedication, have helped ETS grow into the successful event it is today, (iii) to attract and incentivize readers to participate or even organize future events.

\section{HISTORY}

The $1^{\text {st }}$ IEEE European Test Workshop (ETW) was held in Montpellier/Sète, France, during the second week of June 1996. According to the $90+$ participants from academia as well as from industry from all over the world, this event was considered as a great success in the technical aspect, the terrific weather specially ordered by the organizing committee and the gorgeous meals. Since the first organization in 1996, ETW continued to grow and took place on an annual basis until 2003 (including), after which it was elevated to a symposium and renamed to IEEE European Test Symposium (ETS). Table 1 lists the dates and locations for all the organizations of ETW/ETS between 1996 2019, along with the names of the General Chair and Program Chair of each edition. Typically, the event has been taking place during the last week of May. Throughout the years, it has been organized in locations spanning all the geographic regions of Europe, from locations with spectacular natural beauty, historical importance, but also strong technical/industrial relevance.

The best contributions from the $2^{\text {nd }}$ edition of ETW held in 1997 were published in a special issue of the Journal of Electronic Testing: Theory and Applications (JETTA), published by Kluwer. The first formal proceedings of ETW were published in 1999, for the $4^{\text {th }}$ edition held in Constance, Germany. In the following year of 2000, ETW took place at Cascais, $25 \mathrm{~km}$ away from Lisbon, Portugal. This was the first edition sponsored by the IEEE Computer Society - Test Technology Technical Council (TTTC). The first ETS Best Paper Award was given in 2004, the $9^{\text {th }}$ edition of the event. The ETS Fringe workshops were also organized for the first time in 2004 and ever since they have become an integral part of the European Test Week. The ETS Vendor Sessions and Student Forum were initiated in the $11^{\text {th }}$ edition held in 2006 at Southampton, UK. The $14^{\text {th }}$ edition, which was held in Sevilla (Spain) in 2009 included also a post-graduate Student's Forum, consisting of a short oral presentation session and a dedicated student's poster session. The 2009 edition, was also the last edition at which the participants were handed printed proceedings. In 2010, the first edition of the 3-days Test Spring School (TSS@ETS) took place. This school, which typically 
precedes the Symposium, is offered to Ph.D. and M.Sc. students in order to introduce them into the most up-to-date concepts and hot-topics related to test, reliability and security.TSS@ETS has been offered uninterruptedly since 2010 , contributing towards the strong technical and educational activities, which take place during the European Test Week, whose cornerstone event is the European Test Symposium. Another important activity, initiated in the $19^{\text {th }}$ edition of 2014, was the ETS ${ }^{2}$-track on emerging test solutions to provide a one-day informal forum for discussing upcoming problems and solutions in the test industry. The $20^{\text {th }}$ edition of the symposium, which was held in Cluj-Napoca, Romania, was an anniversary edition, and it was the opportunity to acknowledge the most influential papers published by ETS during its first 20 years, in a compendium included in the ETS $20^{\text {th }}$ Anniversary Book.

Table 1 -I EEE ETW/ETS Organization 1996 - 2019

\begin{tabular}{|c|c|}
\hline $\begin{array}{c}\text { Date } \\
\text { Location }\end{array}$ & $\begin{array}{c}\text { General Chair } \\
\text { Program Chair } \\
\end{array}$ \\
\hline $\begin{array}{l}\text { June 14-16, } 1996 \\
\text { Montpellier, France }\end{array}$ & $\begin{array}{l}\text { C. Landrault - LIRMM (FR) } \\
\text { H. J. Wunderlich - University of Stuttgart (DE) } \\
\text { K. Baker - Philips (NL) }\end{array}$ \\
\hline $\begin{array}{l}\text { May 28-30, } 1997 \\
\text { Cagliari, Italy }\end{array}$ & $\begin{array}{l}\text { P. Prinetto - Politecnico di Torino }(I T) \\
\text { T. W. Williams - IBM (US) } \\
\text { H. J. Wunderlich - University of Siegen }(D E)\end{array}$ \\
\hline $\begin{array}{l}\text { May 27-29, } 1998 \\
\text { Barcelona, Spain }\end{array}$ & $\begin{array}{l}\text { J. Figueras - Univ. Politècnica de Catalunya (ES) } \\
\text { T. W. Williams - IBM (US) } \\
\text { C. Landrault - LIRMM (FR) } \\
\text { M. Sachdev - Philips, NL }\end{array}$ \\
\hline $\begin{array}{l}\text { May 25-28,1999 } \\
\text { Constance, Germany }\end{array}$ & $\begin{array}{l}\text { H. J. Wunderlich - University of Stuttgart (DE) } \\
\text { C. Landrault - LIRMM }(F R)\end{array}$ \\
\hline $\begin{array}{l}\text { May 23-26, } 2000 \\
\text { Cascais, Portugal }\end{array}$ & $\begin{array}{l}\text { J. P.Teixeira - IST/INESC }(P T) \\
\text { P. Prinetto - Politecnico di Torino }(I T)\end{array}$ \\
\hline $\begin{array}{l}\text { May } 29 \text { - June 1, } 2001 \\
\text { Stockholm, Sweden }\end{array}$ & $\begin{array}{l}\text { Z. Peng - University of Linköping (SE) } \\
\text { H. J. Wunderlich - University of Stuttgart (DE) }\end{array}$ \\
\hline $\begin{array}{l}\text { May 26-29, } 2002 \\
\text { Corfu, Greece }\end{array}$ & $\begin{array}{l}\text { D. Gizopoulos - University of Piraeus }(G R) \\
\text { A. Paschalis - University of Athens }(G R) \\
\text { S. Hellebrand - University of Innsbruck (AU) }\end{array}$ \\
\hline $\begin{array}{l}\text { May } 25-28,2003 \\
\text { Maastricht, } \\
\text { The Netherlands }\end{array}$ & $\begin{array}{l}\text { E. J. Marinissen - Philips Research (NL) } \\
\text { S. Hellebrand - University of Innsbruck (AU) }\end{array}$ \\
\hline $\begin{array}{l}\text { May 23-26, } 2004 \\
\text { Ajaccio, France }\end{array}$ & $\begin{array}{l}\text { M. Renovell - LIRMM (FR) } \\
\text { P. Prinetto - Politecnico di Torino (IT) }\end{array}$ \\
\hline $\begin{array}{l}\text { May 22-25, } 2005 \\
\text { Tallinn, Estonia }\end{array}$ & $\begin{array}{l}\text { R. Ubar - Tallinn Univ. of Technology (EE) } \\
\text { P. Prinetto - Politecnico di Torino (IT) } \\
\text { M. Renovell - LIRMM (FR) }\end{array}$ \\
\hline $\begin{array}{l}\text { May 21-25, } 2006 \\
\text { Southampton, } \\
\text { United Kingdom }\end{array}$ & $\begin{array}{l}\text { B. Al-Hashimi - Univ. of Southampton (UK) } \\
\text { E. J. Marinissen - Philips Research }(N L)\end{array}$ \\
\hline $\begin{array}{l}\text { May 20-24, } 2007 \\
\text { Freiburg, Germany }\end{array}$ & $\begin{array}{l}\text { B. Becker - University of Freiburg }(D E) \\
\text { Z. Peng - University of Linköping }(S E)\end{array}$ \\
\hline $\begin{array}{l}\text { May 25-29, } 2008 \\
\text { Lago Maggiore, Italy }\end{array}$ & $\begin{array}{l}\text { M. Sonza Reorda - Politecnico di Torino (IT) } \\
\text { P. Girard - LIRMM }(F R)\end{array}$ \\
\hline $\begin{array}{l}\text { May 25-29, } 2009 \\
\text { Sevilla, Spain }\end{array}$ & $\begin{array}{l}\text { J. L. Huertas Diaz - IMSE-CNM }(S P) \\
\text { O. Novak - Czech Technical University }(C Z) \\
\text { J.- P.Teixeira - IST/INESC }(P T)\end{array}$ \\
\hline $\begin{array}{l}\text { May 24-28, } 2010 \\
\text { Prague, } \\
\text { Czech Republic }\end{array}$ & $\begin{array}{l}\text { O. Novak - Czech Technical University (CZ) } \\
\text { S. Hellebrand - Paderborn University }(D E)\end{array}$ \\
\hline $\begin{array}{l}\text { May 23-27, } 2011 \\
\text { Trondheim, Norway }\end{array}$ & $\begin{array}{l}\text { E. J. Aas - Norwegian U. of Science (NO) } \\
\text { E. Larsson, University of Linköping }(S E)\end{array}$ \\
\hline $\begin{array}{l}\text { May } 28 \text { - June } 1,2012 \\
\text { Annecy, France }\end{array}$ & $\begin{array}{l}\text { L. Anghel - TIMA (FR) } \\
\text { M. Violante - Politecnico di Torino (IT) }\end{array}$ \\
\hline $\begin{array}{l}\text { May 27-31, } 2013 \\
\text { Avignon, France }\end{array}$ & $\begin{array}{l}\text { P. Girard - LIRMM (FR) } \\
\text { Z. Peng - University of Linköping (SE) }\end{array}$ \\
\hline $\begin{array}{l}\text { May 26-30, } 2014 \\
\text { Paderborn, Germany }\end{array}$ & $\begin{array}{l}\text { S. Hellebrand - Paderborn University }(D E) \\
\text { J. Tyszer - Poznan University }(P L)\end{array}$ \\
\hline $\begin{array}{l}\text { May 25-29, } 2015 \\
\text { Cluj-Napoca, Romania }\end{array}$ & $\begin{array}{l}\text { L. Miclea - Techn. Univ. of Cluj-Napoca (RO) } \\
\text { P. Prinetto - Politecnico di Torino (IT) }\end{array}$ \\
\hline May 23-27, 2016 & S. Hamdioui - Technical Univ. of Delft (NL) \\
\hline
\end{tabular}

\begin{tabular}{|l|l|}
\hline $\begin{array}{l}\text { Amsterdam, } \\
\text { The Netherlands }\end{array}$ & G. Di Natale - LIRMM (FR) \\
\hline $\begin{array}{l}\text { May 22-26, 2017 } \\
\text { Limassol, Cyprus }\end{array}$ & $\begin{array}{l}\text { M. K. Michael - University of Cyprus (CY) } \\
\text { H.-G. Stratigopoulos - UPMC/CNRS/LIP6 (FR) }\end{array}$ \\
\hline $\begin{array}{l}\text { May 28 - June 1, 2018 } \\
\text { Bremen, Germany }\end{array}$ & $\begin{array}{l}\text { R. Drechsler - University of Bremen (DE) } \\
\text { S. Eggersglüß - Mentor, A Siemens Business (DE) } \\
\text { B. Becker - University of Freiburg (DE) }\end{array}$ \\
\hline $\begin{array}{l}\text { May 27-31, 2019 } \begin{array}{l}\text { Baden-Baden, } \\
\text { Germany }\end{array} \\
\text { M. Tahoori - Karlsruhe Institute of Tech. (DE) }\end{array}$ & S. Hellebrand - Paderborn University (DE) \\
\hline
\end{tabular}

Through the years, the European Test Symposium has changed the format of its sessions; however, two categories have always been represented, dedicated to peer-reviewed scientific contributions. The papers accepted for presentation at ETS are in 2 formats: accepted as regular papers and accepted as posters. Figure 1 illustrates the number of accepted papers in these two categories over the course of ETS history. The posters have been published initially in the informal proceedings and from 2010 corresponding extended abstracts were included in the formal proceedings. Today, each work presented as poster has a 2-page paper included in the IEEE proceedings. In addition to the peerreviewed scientific contributions, the technical program was enriched every year with specific sessions. From the 1998 edition, the technical program included 1 keynote address, technical sessions dedicated to industrial participants and panel sessions. Later-on break-out sessions have been added (from the 2000 to 2003 edition), embedded tutorials (from the 2003 edition until today), special sessions (were organized for most editions starting from 2007), student sessions (were sporadically organized in 2009, 2011, 2018 and 2019), workshop-type papers (in the 2013 and 2019 edition), and a special track with a very high industrial character, the ETS $^{2}$ (from the 2014 edition of ETS). The Industrial/Vendor Sessions are dedicated to commercial vendors and give them the opportunity to give technical presentations in a track parallel to the technical paper sessions. These presentations are listed in the symposium program along with the technical sessions, and target the ETS technical audience. The Embedded Tutorial Sessions address important and trendy topics that are of strong interest to the ETS community. The Special Sessions are meant to target hot and emerging test topics complementary to the regular sessions of the symposium. One of the objectives is also to cover cross topics, i.e. topics considered "border line" for the test community, but have, or are expected to have, a significant impact on the field. The Student Sessions (currently named PhD Forum) provide an excellent opportunity for $\mathrm{PhD}$ students to present their ongoing work and get feedback from experts in the field. The Embedded Workshop Sessions provide a forum for work in progress as well as for case studies. The ETS ${ }^{2}$ Sessions have a very high industrial character, where industry experts introduce emerging technical issues in the broad area of test, which will be discussed with the audience. Figure 2 illustrates the diversity of the ETS technical program over the years, by showing the constant increase of the types of sessions organized by our symposium. The same trend is observed in the topic diversity. Figure 3 illustrates the number of topics of interests listed every year in the call for papers. If in 1996 only 10 major topics were identified in the call for papers, the 2020 edition, lists 44 topics. This shows the dynamism of the ETS community. With the increase in the number of topics covered by the Symposium, the number of experts needed for assuring a high quality program has also increased. If in 2001, the Steering Committee of ETS counted 11 members, today it is constituted by 25 members. The same trend is observed related to the 
Technical Program Committee members, which in 1997 had 33 members and for the 2020 edition, it contains 114 members.

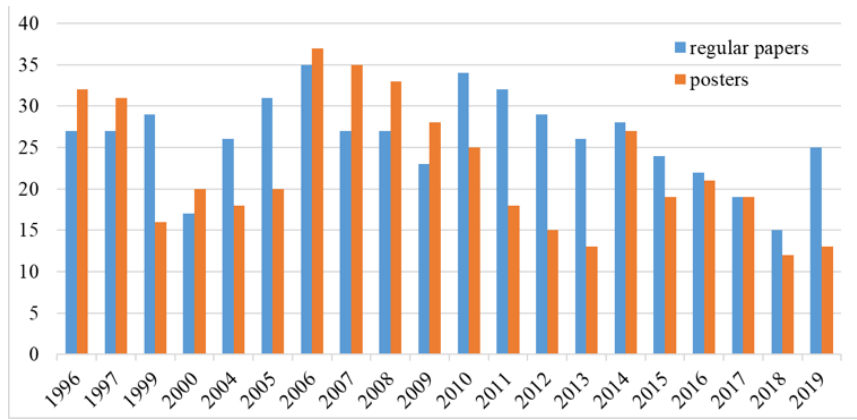

Fig. 1 - Number of accepted peer-reviewed papers per ETS edition

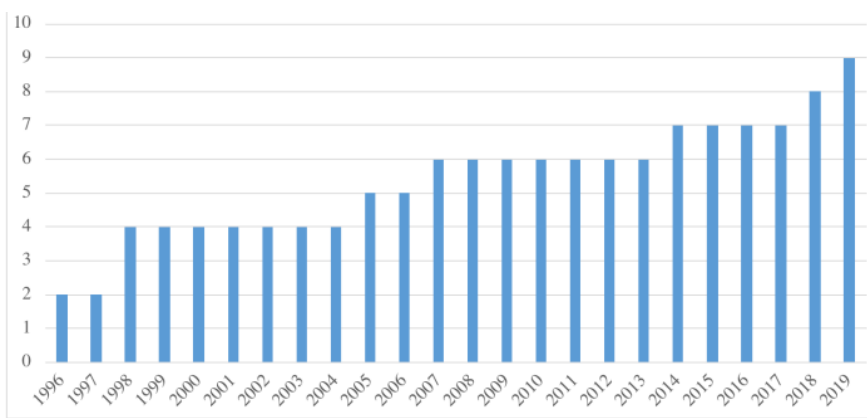

Fig. 2 - Number of session types per ETS edition

60

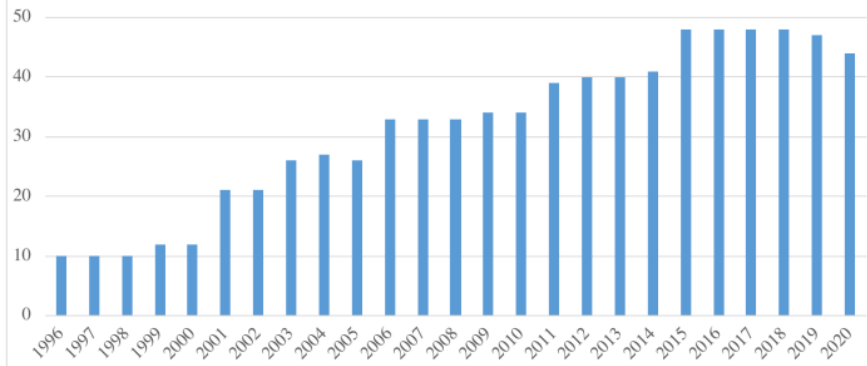

Fig. 3 - Number of topics covered by the ETS announced in the Call for Papers per ETS edition

Table 2 - The IEEE ETS Best Paper Awards

\begin{tabular}{|c|l|}
\hline Year & Title and Authors \\
\hline 2004 & $\begin{array}{l}\text { "Dynamic Read Destructive Fault in Embedded-SRAMs: Analysis } \\
\text { and March Test Solution" by L. Dilillo, P. Girard, S. } \\
\text { Pravossoudovitch, A. Virazel (LIRMM - CNRS /Univ Montpellier } \\
\text { 2 - France), S. Borri, M. Hage-Hassan (Infineon Technologies } \\
\text { France - France) }\end{array}$ \\
\hline 2005 & $\begin{array}{l}\text { Multiple errors produced by single upsets in FPGA configuration } \\
\text { memory: a possible solution by M. Violante, M. Sonza Reorda, L. } \\
\text { Sterpone (Politecnico di Torino -Italy) }\end{array}$ \\
\hline 2006 & $\begin{array}{l}\text { "Analogue Network of Converters": A DFT Technique to Test a } \\
\text { Complete Set of ADCs and DACs Embedded in a Complex SiP or } \\
\text { SOC by V. Kerzérho (LIRMM, France), P. Cauvet (Philips } \\
\text { Semiconductors, France), S. Bernard, F. Azaïs, M. Comte, M. } \\
\text { Renovell (LIRMM, France) }\end{array}$ \\
\hline 2007 & $\begin{array}{l}\text { "Adaptive Debug and Diagnosis Without Fault Dictionaries" by S. } \\
\text { Holst, H.-J. Wunderlich (University of Stuttgart, Germany) }\end{array}$ \\
\hline 2008 & $\begin{array}{l}\text { "Critical Path Selection For Delay Test Considering Coupling } \\
\text { Noise" by R. Tayade, J. Abraham (University of Texas, USA) }\end{array}$ \\
\hline 2009 & $\begin{array}{l}\text { "Defect Filter for Alternate RF Test" by H. Stratigopoulos, S. Mir, } \\
\text { (TIMA Laboratory, France), E. Acar, (Duke University, USA), S. } \\
\text { Ozev, (Arizona State University, USA) }\end{array}$ \\
\hline
\end{tabular}

\begin{tabular}{|c|c|}
\hline 2010 & $\begin{array}{l}\text { "Diagnosis of Failing Scan Cells through Orthogonal Response } \\
\text { Compaction" by B. Benware, G. Mrugalski, A. Pogiel, J. Rajski } \\
\text { (Mentor Graphics Corporation USA) J. Solecki, J. Tyszer (Poznań } \\
\text { University of Technology, Poland) }\end{array}$ \\
\hline 2011 & $\begin{array}{l}\text { "A Robust Metric For Screening Outliers From Analogue Product } \\
\text { Manufacturing Tests Responses" by S. Krishnan, (TNO The } \\
\text { Netherlands), H. Kerkhoff (University Of Twente, The Netherlands) }\end{array}$ \\
\hline 2012 & $\begin{array}{l}\text { "An Enhanced Reduced Code Linearity Test Technique For } \\
\text { Multibit/Stage Pipelined ADCs" by A. Laraba, H. Stratigopoulos, S. } \\
\text { Mir (TIMA Laboratory, France), H. Naudet and C. Forel (STM, } \\
\text { France) }\end{array}$ \\
\hline 2013 & $\begin{array}{l}\text { "Information-Theoretic Syndrome and Root-Cause Analysis for } \\
\text { Guiding Board-Level Fault Diagnosis" by Fangming Ye (Duke } \\
\text { University, USA), Zhaobo Zhang (Huawei Technologies, USA), } \\
\text { Krishnendu Chakrabarty (Duke University, US), Xinli GU (Huawei } \\
\text { Technologies, USA) }\end{array}$ \\
\hline 2014 & $\begin{array}{l}\text { "Variation-Aware Deterministic ATPG" by M. Sauer (University of } \\
\text { Freiburg, Germany), I. Polian (University of Passau, Germany), M. } \\
\text { E. Imhof, A. Mumtaz, E. Schneider (University of Stuttgart, } \\
\text { Germany), Alexander Czutro (University of Freiburg, Germany), } \\
\text { Hans-Joachim Wunderlich (University of Stuttgart, Germany), } \\
\text { Bernd Becker (University of Freiburg, Germany) }\end{array}$ \\
\hline 2015 & $\begin{array}{l}\text { Frequency Jitter Estimator for SoCs" by H. Le Gall, R. } \\
\text { n, M. Valka, S. Mir, H. Stratigopoulos, E. Simeu (TIMA, }\end{array}$ \\
\hline 2016 & $\begin{array}{l}\text { "A Self-Reconfiguring IEEE } 1687 \text { Network for Fault Modeling" by } \\
\text { F. Ghani Zadegan, D. Nikolov, E. Larsson (Lund University, } \\
\text { Sweeden) }\end{array}$ \\
\hline 2017 & $\begin{array}{l}\text { "Automatic Testing of Analog ICs for Latent Defects using Topology } \\
\text { Modification" by N. Xama, A. Coyette, B. Esen, W. Dobbelaere, R. } \\
\text { Vanhooren, G. Gielen (KU Leuven and ON Semiconductor - } \\
\text { Belgium) }\end{array}$ \\
\hline 2018 & $\begin{array}{l}\text { "Assisted test design for non-intrusive machine learning indirect test } \\
\text { of millimeter-wave circuits" by F. Ciliciy, M. J. Barragan, S. Mir, E. } \\
\text { Lauga-Larrozey, S. Bourdel (Université Grenoble Alpes - France) }\end{array}$ \\
\hline
\end{tabular}

\section{IEEE EUROPEAN TEST SYMPOSIUM 2019}

This year's edition of ETS took place in Baden-Baden, Germany and it was organized by the Karlsruhe Institute of Technology (KIT), which co-sponsored the event jointly with the IEEE Council on Electronic Design Automation (CEDA). ETS is the cornerstone event of the European Test Week, which also includes the Test Spring School (TSS) and Fringe Workshops. The main topic for this year's TSS, which precedes the symposium, is Cutting Edge Approaches for Test. Three Fringe Workshops were organized immediately following ETS'19, namely the 4th International Test Standards Application (TESTA) Workshop, which focused on test standards, the 8th Workshop on Trustworthy Manufacturing and Utilization of Secure Devices (TRUDEVICE), as well as the Secure Hardware, Integrity and preVention of Attacks Workshop (SHIVA).

ETS'19 received a significant number of scientific paper submissions from 28 countries all over the world. Each paper was evaluated by 5 expert reviewers, on average. Based on the written reviews and follow-up online discussions among the reviewers, the Organizing Committee and the Topic Chairs convened in Karlsruhe, Germany, on February 8, 2019, and recommended to accept 25 papers for oral presentation, distributed over 9 regular sessions, and 13 papers for poster presentation, distributed over 3 poster sessions. An Award Committee has been formed and has selected the best paper based on the reviewers' comments and the ratings provided by the attendees. The authors of the best paper will receive the Best Paper Award during the opening ceremony of ETS'20. 
Apart from scientific paper presentations and posters, the ETS' 19 program included 3 plenary keynote addresses, 2 onehour embedded tutorials and 2 TSS@ETS Monday tutorials, 2 panel sessions, 3 special sessions, the PhD contest, and several vendor sessions. In addition, ETS featured a special session on Emerging Test Strategies (ETS $)$, where new issues are presented by the industry and are discussed in an informal atmosphere. Furthermore, the new Embedded Workshop track was dedicated to work in progress and case studies, while the newly established $\mathrm{PhD}$ Forum provided an excellent opportunity for $\mathrm{PhD}$ students to present their ongoing work and get feedback from experts in the field.

The ETS'19 was well attended, with more than 260 participants from 28 countries spanning over 4 continents, as it is illustrated in Fig. 4.

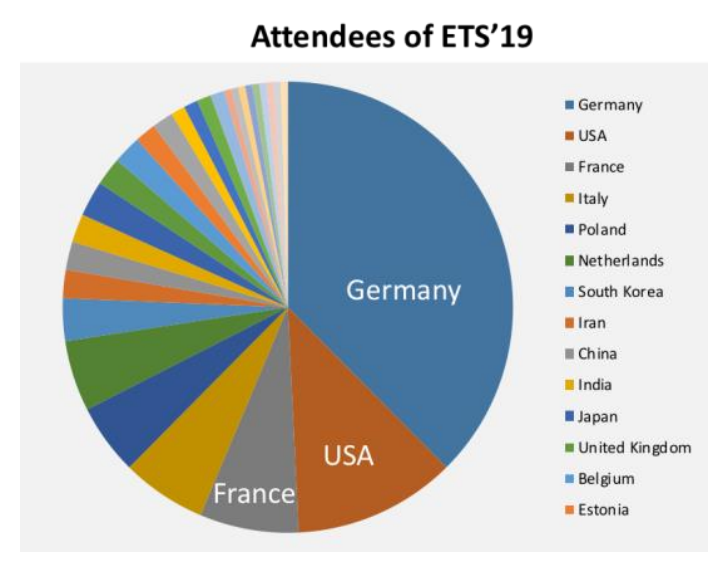

Fig. 4 - ETS'19 participants per country of origin

\section{Future EDITIONS OF IEEE EUROPEAN TEST SYMPOSIUM}

In 2020 we will celebrate the 25 th edition of ETS. It will take place on May 25-29 in the Radisson Blu Sky Hotel in Tallinn, Estonia. The city is known for the picturesque Old Town with its medieval architecture. It is organized by the Tallinn University of Technology (TalTech), which co-sponsors the event jointly with the IEEE Council on Electronic Design Automation (CEDA). The General Chairs of the ETS'20 are: Artur Jutman (Testonica Lab) and Jaan Raik (TalTech), while the program chairs are: Görschwin Fey (TU Hamburg) and Maksim Jenihhin (TalTech).

In addition to scientific paper submissions, for the first time in 2020 ETS will offer a track for informal contributions dedicated to early hot ideas and relevant case studies. A PhD forum will also be organized where students will present their work in the form of a poster. The Ph.D. forum selection committee will review all the student works checking their technical content and the presentation capacity of the candidates, and will select the Best Ph.D. forum work. The Ph.D. Forum Award will be announced during the ETS'20 closing session. A Test Spring School and Fringe Workshops will be organized in conjunction with ETS'20.

ETS'20 seeks original, unpublished contributions of the following types:

- Scientific Papers for the Formal Proceedings, presenting novel and complete research work
- Informal Contributions including case studies and work in progress on hot topics

- $\quad$ PhD Forum Contributions from students eager to discuss their on-going research

- $\quad$ Proposals for Panels, Embedded Tutorials, Special Sessions and Fringe Workshops

- Vendor Presentations focusing on new features of test related products

Detailed submission information and guidelines are posted on the ETS'20 web page. Key Dates for Scientific Papers:

- Submission deadline December 9, 2019;

- Notification of acceptance February 13, 2020

- Camera-ready manuscript April 1, 2020.

The $26^{\text {th }}$ edition of ETS will take place in Bruges, Belgium.

\section{CONSTituting NEW ETS VEnUES}

The Steering Committee obtains proposals for new ETS venues through an open call for proposals. Submitting a proposal implies that the proposers commit to follow the rules provided by the Steering Committee for the organization of ETS.

Individuals or institutions interested to propose and organize a future ETS should follow the following steps. Written proposals for the ETS should be sent to the Chair of the Steering Committee to fulfill the stated deadline. The decision on the ETS will generally be made at least 24 months before the actual event occurrence. Proposals shall list facilities, venue, proposed management, a brief summary of the ETS structure, names of individual(s), who will serve as General Chair(s), as Program Chair, and any other information required by the Steering Committee. At least one of the General Chair(s) shall be from the country hosting the ETS. The Steering Committee reviews proposals and may seek advice from anonymous reviewers. If the evaluation is positive, the Steering Committee will accept the proposal and appoint the General Chair(s) and the Program Chair.

The General Chair will set up the Organizing Committee, will prepare a detailed budget using the Sponsor appropriate forms and submit the forms according to the rules and deadlines of the Sponsor(s). The budget must be preliminarily approved by the Steering Committee before being sent to the Sponsor(s).

In order to support the organization of each event, an Operating Committee (OpCom) is appointed, composed of local organizers and experienced members of the ETS Steering Committee. The OpCom visits the locations of the upcoming edition and periodically interacts with the organizers since they are selected in order to guide and support them towards a new successful ETS edition.

\section{CONCLUSIONS}

The objective of the European Test Symposium (ETS) is to provide a first class forum in Europe dedicated to test technology topics. At ETS, test and design professionals can confront the challenges faced by test community and learn how these challenges are being addressed by academia and industry. 